\title{
Brain-derived neurotrophic factor promotes bovine oocyte cytoplasmic competence for embryo development
}

\author{
S J Martins da Silva, J O Gardner ${ }^{1}$, J E Taylor ${ }^{1}$, A Springbett ${ }^{1}$, P A De Sousa ${ }^{1}$ and R A Anderson \\ MRC Human Reproductive Sciences Unit, Centre for Reproductive Biology, 49 Little France Crescent, \\ Edinburgh, EH16 4SB, UK and ${ }^{1}$ Division of Gene Function and Development, Roslin Institute, Roslin, \\ Midlothian, EH25 9PS, UK
}

Correspondence should be addressed to R A Anderson; Email: r.a.anderson@hrsu.mrc.ac.uk

\begin{abstract}
The ability of an oocyte to support early embryonic development requires both nuclear and cytoplasmic maturation. We have investigated the effects of brain-derived neurotrophic factor (BDNF) on maturation of the bovine oocyte and embryo development after parthenogenetic activation. By RT-PCR and immunohistochemistry, cumulus and oocytes were shown to express mRNA and protein for BDNF and the p75 common neurotrophin receptor. However, mRNA for the BDNF-specific full length and truncated isoforms of the TrkB receptor are only detected in cumulus, suggesting that oocytes and cumulus differ in their capacity to respond to neurotrophin signalling. In in vitro maturation experiments, the proportion of cumulus oocyte complexes maturing to metaphase II was not altered by BDNF in groups lacking fetal calf serum (FCS), but was significantly lower than the positive control containing $10 \%$ FCS $(P<0.01)$. However, after maturation, the proportion of parthenogenetically activated oocytes forming blastocysts was highest for $10 \mathrm{ng} / \mathrm{ml} \mathrm{BDNF}(24 \%, n=95)$ followed by $100 \mathrm{ng} / \mathrm{ml} \mathrm{BDNF}(18 \%$, $n=91)$ and $10 \%$ FCS $(15 \%, n=103)$, which in turn were greater than no serum $(10 \%, n=83 ; P<0.01)$. Maturation in the presence of a BDNF blocking antibody resulted in a blastocyst yield that was comparable to the absence of serum, and lower than in the presence of BDNF $(P<0.01)$. Similar effects on progression to metaphase II and blastocyst formation were observed using oocytes matured without cumulus. Together, these results provide the first evidence for a role for neurotrophins in promoting oocyte cytoplasmic competence to support embryonic development, despite being insufficient in the absence of serum to enhance nuclear maturation.

Reproduction (2005) 129 423-434
\end{abstract}

\section{Introduction}

Oocyte competence to support development after fertilisation or parthenogenetic activation is acquired gradually over the course of oogenesis and folliculogenesis and is completed during meiotic maturation (Eppig 2001, Liu \& Aoki 2002, Liu et al. 2003). At this time the meiotic segregation of chromatin is accompanied by critical changes in oocyte cytoplasm that remain poorly defined. The significance of these changes is illustrated by the wide differences observed in embryo developmental competence following variations in oocyte in vitro maturation culture conditions (Keskintepe \& Brackett 1996, Krisher \& Bavister 1999, Watson et al. 2000). A broad range of factors has been found to improve meiotic maturation in vitro and subsequent embryo developmental potential. These include supplementation of culture media with follicular fluid or serum, or specific gonadotrophins, steroid and thyroid hormones, retinoids, and different energy substrates and nutrients. These can benefit oocytes directly or via cumulus cells (see reviews by Sutton et al. (2003), Chian et al. (2004)). Specific growth factors identified as intra-ovarian regulators of oocyte maturation that have been shown to be beneficial to bovine oocyte developmental competence in in vitro studies include epidermal growth factor (EGF), insulin-like growth factor I (IGF-I), activin A, inhibin A, and midkine, a heparin-binding growth factor (Lonergan et al. 1996, Stock et al. 1997, Rieger et al. 1998, Silva \& Knight 1998, Ikeda et al. 2000).

There is increasing evidence of a role for neurotrophins in ovarian development and function, including oocyte maturation. Neurotrophins are a family of related growth factors initially identified to be important for regulation of neuronal survival and differentiation, but which have also been described in a variety of non-neuronal tissues including the cardiovascular, immune, endocrine and reproductive systems (Matsuda et al. 1988, Polak et al. 1993). They include nerve growth factor (NGF), brain-derived neurotrophic factor (BDNF), and neurotrophins 3 and 4 (NT3 
and NT4). Neurotrophins are unique in that they utilise two different receptors to mediate their biological actions: tyrosine kinase (Trk) receptors encoded by the trk protooncogene family (Trk A-C and truncated isoforms), and the p75 receptor, a member of the tumour necrosis factor (TNF) receptor superfamily (Bibel \& Barde 2000, Rabizadeh \& Bredesen 2003). The p75 receptor is widely expressed and binds all neurotrophins. By contrast, the Trk receptors show selective affinity for different neurotrophins (i.e. TrkA for NGF, TrkB for BDNF and NT4 and TrkC for NT3). Splice variants and truncated isoforms of Trk receptors lacking intracellular tyrosine kinase domains have also been identified (Bibel \& Barde 2000)

BDNF and TrkB have been identified in the adult avian ovary (Jensen \& Johnson 2001) and NT4 expression has also been localised to the oocyte in both rodent (Dissen et al. 1995) and Xenopus (Ibanez et al. 1992). TrkB expression appears to be central to the normal formation of primordial follicles that occur in the ovary in the few days following birth in the rodent (Spears et al. 2003), and for oocyte survival during early follicular growth (Paredes et al. 2004), an effect that may be predominantly mediated by truncated TrkB receptors. Mice carrying a null mutation of the NGF gene show deficient development of primordial follicles (Dissen et al. 2001). A direct effect of BDNF on murine oocyte maturation in vitro has also been reported, with increased first polar body extrusion rate in oocytes stripped of cumulus prior to maturation (Seifer et al. 2002a). BDNF is present in human follicular fluid (Seifer et al. 2003), and there is evidence for increased secretion of BDNF by cumulus cells, but not mural granulosa cells, in response to cAMP (Seifer et al. 2002a). These data suggest that cumulus-derived BDNF may be involved in oocyte maturation, and it is possible that its production is stimulated by gonadotrophins.

In the present study we have investigated the effects of BDNF on maturation of the bovine oocyte as well as implications for embryo development after parthenogenetic activation. Parthenogenesis provides a means of assessing oocyte cytoplasmic competence to elicit development independently of sperm mediated factors, and is an accepted standard to assess oocyte viability for cloning and nuclear reprogramming (De Sousa et al. 2002, Liu \& Aoki 2002). We provide evidence that cumulus cells and oocytes may have different capacities to respond to neurotrophin signalling, and that neurotrophin signalling during maturation benefits oocyte cytoplasmic competence but not nuclear maturation.

\section{Materials and Methods}

\section{Tissues}

Bovine ovaries were collected from a local abattoir and kept warm during transportation. In the laboratory, ovaries were washed in Dulbecco's phosphate-buffered saline (PBS; Oxoid Ltd, Basingstoke, Hampshire, UK) at $38{ }^{\circ} \mathrm{C}$, after which follicles measuring $4-8 \mathrm{~mm}$ were aspirated.
For immunohistochemistry, all tissue was fixed in Bouin's fluid overnight, and transferred to $70 \%$ ethanol before paraffin embedding and sectioning. To facilitate their handling prior to fixation, cumulus oocyte complexes (COCs) were first embedded in $50 \mu \mathrm{l}$ droplets of collagen solution prepared by dissolving $4.2 \mathrm{mg}$ type I rat-tail collagen (Sigma, Poole, UK) in $1 \mathrm{ml} 0.1 \mathrm{M}$ acetic acid (BDH) and mixing with an equal volume of $2 \times$ TCM199 (Sigma), $\mathrm{pH} 7.2$, immediately before use. Droplets containing COCs were then incubated at $37^{\circ} \mathrm{C}$ for $10 \mathrm{~min}$ to set (Izadyar et al. 1998). For RNA isolation, ovaries were diced to $5 \mathrm{~mm}^{3}$ cubes and COCs, denuded oocytes and cumulus were snap frozen and stored at $-70^{\circ} \mathrm{C}$.

\section{Extraction of RNA and synthesis and amplification of CDNA}

Total RNA was extracted using a RNAeasy mini kit (Qiagen, Crawley, UK) as previously described (Young et al. 1998). Reverse transcription using a bulk first strand cDNA synthesis kit (Amersham Biosciences, Bucks, UK) was followed by PCR on $2 \mu \mathrm{l}$ cDNA samples using $2 \times$ thermostart PCR mastermix as per manufacturers instructions (Abgene, Epson, UK). Specific primers for each gene are given in Table 1. For each gene, negative controls to confirm the absence of genomic DNA consisted of PCR on RNA without performing first-strand cDNA synthesis (RT-), and water. A further control tube was included and run in paraIlel as a blank for Qiagen reagents (non-embryo control). The identity of all PCR products was confirmed by direct sequencing using an Applied Biosystems 373A automated sequencer (Applied Biosystems, Foster City, CA, USA).

\section{Immunohistochemistry}

Immunohistochemistry was performed on sections of whole ovary and COCs. Sections $(5 \mu \mathrm{m})$ were mounted on BDH Superfrost Plus slides (BDH Laboratory Supplies, Merck Ltd, Lutterworth, UK) and dried overnight at $50^{\circ} \mathrm{C}$ before processing for immunohistochemistry as previously described (Anderson et al. 2002). Briefly, slides were incubated in $3 \% \mathrm{H}_{2} \mathrm{O}_{2}$ in methanol for $30 \mathrm{~min}$ to inhibit

Table 1 PCR primer sequences.

\begin{tabular}{|c|c|c|c|}
\hline Gene $^{a}$ & Primer & Sequence & $\begin{array}{l}\text { Product } \\
\text { size }(b p)\end{array}$ \\
\hline \multirow[t]{2}{*}{ BDNF } & Forward & 5'-CATGGGACTCTGGAGAGCAT-3' & \multirow[t]{2}{*}{198} \\
\hline & Reverse & 5'-CAAAGGCACTTGACTGCTGA-3' & \\
\hline \multirow[t]{2}{*}{ Trk B } & Forward & 5'GGCCCAGATGCTGTCATTAT- $3^{\prime}$ & \multirow[t]{2}{*}{206} \\
\hline & Reverse & 5'-TCCTGCTCAGGACAGAGGTT-3' & \\
\hline \multirow{2}{*}{$\begin{array}{c}\text { Truncated } \\
\text { Trk B }\end{array}$} & Forward & 5'CATGTTACCAATCACACGGAGTA-3' & \multirow[t]{2}{*}{430} \\
\hline & Reverse & $5^{\prime}$ CCATCCAGTGGGATCTTATGAAA- $3^{\prime}$ & \\
\hline \multirow[t]{2}{*}{ p75 } & Forward & 5'TGGACAGCGTGACCTTCTC-3' & \multirow[t]{2}{*}{153} \\
\hline & Reverse & 5'-TCGTCTCGTCCTGGTAATAGC-3' & \\
\hline
\end{tabular}

${ }^{a}$ Gene specific primers were designed based on homology to Genbank sequences specified by the following accession numbers: BDNF X97914; Trk B, NM_006180; Truncated Trk B, AF508964; p75, (AF228020). 
endogenous peroxidase activity. After rinsing in distilled water, slides were washed twice in Tris-buffered saline (TBS; $0.05 \mathrm{M}$ Tris, $0.85 \% \mathrm{NaCl}, \mathrm{pH}$ 7.6) for $5 \mathrm{~min}$ and blocked for $30 \mathrm{~min}$ in serum (Diagnostics Scotland, Carluke, UK) diluted 1:5 in TBS containing 5\% bovine serum albumin. Sections were then blocked with avidin and biotin (both from Vector, Peterborough, UK) with washes in TBS in between. The following primary antibodies were used: BDNF (N20) (rabbit polyclonal; Santa-Cruz Biotechnology, CA, USA) which was used at 1:100 as previously described (Schneider et al. 2001); TrkB (chicken polyclonal; Promega, Southampton, UK) used at 1:25; p75 (mouse monoclonal; Neomarkers, Soham, Cambridgeshire, UK) used at 1:25. All were incubated at $4{ }^{\circ} \mathrm{C}$ overnight. Sections were then washed and incubated for 30 min with swine anti-rabbit (Dako, Cambridge, UK), donkey anti-chicken (The Jackson Laboratory, Bar Harbor, ME, USA) or rabbit anti-mouse (Dako) biotinylated secondary antibody as appropriate, at a dilution of 1:500. Following washes in TBS, sections were incubated with avidin-biotin-horseradish peroxidase linked complex (Dako) according to the manufacturer's instructions. Bound antibody was visualised using 3,3'-diaminobenzidine tetrahydrochloride (Dako). Non-immune serum was used in place of primary antibody for negative controls as well as BDNF blocking peptide (sc-546 P, Santa Cruz Biotechnology), whilst rat brain was used as a positive control tissue. Sections were counterstained with haematoxylin, dehydrated, mounted and visualised by light microscopy. Images were captured using an Olympus Provis microscope (Olympus Optical Co., London, UK) equipped with Kodak, DCS330 camera (Eastman Kodak Rochester, NY, USA).

\section{Oocyte maturation in vitro}

Follicular aspirate was maintained at $38^{\circ} \mathrm{C}$ and allowed to settle. The cellular debris was then transferred to a petridish containing HEPES-buffered TCM199 (Sigma) with $10 \%$ (heat inactivated) FCS to allow sorting and selection of COCs. All procedures were carried out in a laminar flow hood using a Leica microscope (Leica, Wetzlar, Germany) with heated stage at $38^{\circ} \mathrm{C}$. COCs were transferred through $3 \times 1.5 \mathrm{ml}$ volumes of HEPES-buffered TCM199 with $10 \%$ FCS before transfer in a minimal volume to $1.5 \mathrm{ml}$ of base maturation medium for random allocation into maturation treatment groups. The base medium for cumulus enclosed and denuded (see below) oocyte maturation consisted of bicarbonate-buffered TCM199 supplemented with $0.01 \mathrm{lU} / \mathrm{ml}$ follicle stimulating hormone (FSH)(Ovagen: ICPbio, Auckland, New Zealand), $0.125 \mathrm{IU} / \mathrm{ml}$ LH (Sigma) and $2 \mu \mathrm{g} / \mathrm{ml}$ oestradiol (Sigma). In vitro maturation treatments were comprised of culturing 15-25 oocytes in $500 \mu \mathrm{l}$ volume of base medium with no additional supplements (i.e. serum-free negative control), 10\% FCS (positive control), $10-100 \mathrm{ng} / \mathrm{ml}$ of recombinant human BDNF (PeproTech EC Ltd, London, UK), $5 \mu \mathrm{g} / \mathrm{ml}$ monoclonal anti-human BDNF (Sigma) or both $10 \mathrm{ng} / \mathrm{ml}$ recombinant human BDNF and $5 \mu \mathrm{g} / \mathrm{ml}$ monoclonal anti-human BDNF.

COCs were cultured at $38.5^{\circ} \mathrm{C}$ in a humidified incubator with $5 \% \mathrm{CO}_{2}$. After $26 \mathrm{~h}$ maturation culture COCs were stripped and either processed for immunocytochemistry to assess meiotic progression or activated to produce parthenogenetic embryos. Cumulus was stripped from oocytes by a combination of mechanical vortex and incubation in $300 \mathrm{IU} / \mathrm{ml}$ hyaluronidase (Sigma) for 60-90 seconds in serum-free HEPES buffered Synthetic Oviduct Fluid (HEPES SOF) consisting of $108 \mathrm{mM} \mathrm{NaCl}, 7.2 \mathrm{mM}$ $\mathrm{KCl}, 1.2 \mathrm{mM} \mathrm{KH}{ }_{2} \mathrm{PO}_{4}, 5 \mathrm{mM} \mathrm{NaHCO}, 20 \mathrm{mM}$ HEPES, $0.33 \mathrm{mM}$ Na-Pyruvate, $1.7 \mathrm{mM} \mathrm{CaCl} 2,0.5 \mathrm{mM} \mathrm{MgCl} \mathrm{Mg}_{2}$, $3.3 \mathrm{mM}$ Na-Lactate, $1.5 \mathrm{mM}$ glucose, $3 \mathrm{mg} / \mathrm{ml}$ BSA (fatty acid free), $\mathrm{pH} 7.4$, osmolarity 265-275 (Thompson et al. 1995). Enzymatic action was neutralised by transferring oocytes through subsequent washes of $\mathrm{HEPES} \mathrm{SOF}^{+}$supplemented with $10 \%$ FCS.

In a second group of experiments oocytes were stripped of cumulus prior to maturation, and only completely denuded oocytes were selected, and washed in serum-free base maturation medium (see above). Five cumulus-free maturation treatments were evaluated consisting of base medium with no additional supplements (i.e. serum-free), $10 \%$ FCS, $10 \mathrm{ng} / \mathrm{ml}$ of recombinant human BDNF, $5 \mu \mathrm{g} / \mathrm{ml}$ monoclonal anti-human BDNF or both $10 \mathrm{ng} / \mathrm{ml}$ recombinant human BDNF and $5 \mu \mathrm{g} / \mathrm{ml}$ anti-human BDNF. In each experimental replicate, a sixth group of cumulus enclosed oocytes were matured in base maturation media supplemented with $10 \%$ FCS (positive control). As previously, oocytes were cultured at $38.5^{\circ} \mathrm{C}$ in a humidified incubator with $5 \% \mathrm{CO}_{2}$ for $26 \mathrm{~h}$ and subsequently either processed for immunocytochemistry to assess meiotic progression or activated to produce parthenogenetic embryos.

\section{Immunocytochemical analysis of meiotic progression}

Maturation to metaphase II (MII) was assessed by immunocytochemical staining of microtubules to visualise spindle morphology, of microfilaments to visualise cortical membranes and segregation of the first polar body, and DAPI to visualise condensed chromatin. Stripped oocytes were fixed and immunostained for microtubules and microfilaments using a modification of the method described by Messinger \& Albertini (1991). Microtubule stabilising buffer comprising $5 \times \mathrm{SB}\left(0.1 \mathrm{M}\right.$ Pipes (Sigma), $5 \mathrm{mM} \mathrm{MgCl}_{2}, 2.5 \mathrm{mM}$ EGTA pH 6.9 in $\mathrm{NaOH}), 1 \mathrm{M}$ DTT, deuterium oxide (Aldrich, Gillingham, UK) and distilled water was incubated with Triton X100 (BDH) and 37\% formaldehyde to make complex fix. Stripped oocytes were incubated in complex fix for $30 \mathrm{~min}$ at $37^{\circ} \mathrm{C}$ and then washed 3 times in $0.1 \%$ goat serum before blocking in $10 \%$ goat serum for $1 \mathrm{~h}$ at room temperature. Oocyte groups were then incubated in the dark at $37^{\circ} \mathrm{C}$ for $1 \mathrm{~h}$ in $50 \mu \mathrm{l}$ droplets of $5 \%$ goat serum with rhodamine phalloidin and anti-tubulin FITC, washed 3 times in $10 \%$ goat serum and then mounted in Vectashield and DAPI (Vector). Oocytes were partially squashed with a 
coverslip that was then sealed using clear nail varnish. Slides were visualised using fluorescent microscopy and each oocyte scored for meiotic progression. Oocytes were scored as MII arrested if they exhibited an alignment of chromatin along the centre of the spindle and extrusion of a single polar body containing chromatin.

\section{Parthenogenetic activation and embryo culture}

Cumulus-free oocytes were activated for $5 \mathrm{~min}$ at room temperature with $5 \mu \mathrm{M}$ ionomycin (Sigma) in HEPES SOF and $10 \%$ FCS. They were subsequently washed twice in HEPES SOF with $10 \%$ FCS and then washed in SOFaaBSA culture medium (i.e. HEPES-free SOF supplemented with $1 \mathrm{mM}$-L-Glutamine, $8 \mathrm{mg} / \mathrm{ml}$ BSA (fatty acid free), $1 \times$ essential amino acids (Sigma B6766), $1 \times$ non-essential amino acids (Sigma M7145), pH 7.4, osmolarity 265-275) (Thompson et al. 1995, Walker et al. 1996). Oocytes were then incubated for $4 \mathrm{~h}$ in SOFaaBSA containing $2.5 \mathrm{mM}$ 6-dimethylaminopurine (6-DMAP; Sigma) and $35.5 \mu \mathrm{M}$ cycloheximide (Sigma) at $38.5{ }^{\circ} \mathrm{C}$ in humidified $5 \% \mathrm{O}_{2}$, $5 \% \mathrm{CO}_{2}$ and $90 \% \mathrm{~N}_{2}$ atmosphere. Following activation, oocytes were washed three times in SOFaaBSA and transferred into 4-well Nunc plates for final culture in $500 \mu \mathrm{l}$ SOFaaBSA under mineral oil. Embryos were examined for cleavage at $24 \mathrm{~h}$ post activation (day 1 ), and for blastocyst development on day 7. Embryo culture media was supplemented with FCS to a final concentration of $9 \%$ on day 5 of culture. Blastocyst cell nuclei were stained by addition of Hoescht 33342 (Sigma) to the culture medium at $5 \mathrm{ug} / \mathrm{ml}$ and incubated for $15 \mathrm{~min}$. Subsequently, embryos were mounted on glass slides and visualised by fluorescence microscopy to determine their nuclear number.

\section{Statistical analysis}

The developmental data (proportion of oocytes reaching MII and blastocysts) were analysed by logistic regression. Effects of replicate and treatment, and their interaction were incorporated into the analysis. Also, the treatment effect was split into contrasts between one or two treatments and the rest in order to examine the differences between them. The interaction between treatment and replicate was found to be not significant. Results from all replicates were pooled for presentation. The data on blastocyst nuclei count were analysed by ANOVA to look for treatment and replicate effects.

\section{Results}

\section{Evaluation of BDNF and receptor $m R N A$ expression}

We first considered whether mRNA for BDNF and associated receptors could be detected in RNA isolated from bovine ovary COCs, and cumulus and oocytes separately. Amplification products of the expected size corresponding to BDNF (198 bp), TrkB (206 bp), truncated TrkB (430 bp) and p75 (153 bp) receptors were first detected in RNA extracted from bovine ovarian tissue and confirmed by DNA sequencing (data not shown). All gene transcripts were also detected in RNA isolated from COCs, and cumulus cells alone (Fig. 1). Neither full length or truncated TrkB was ever detected in oocytes in six independent trials which simultaneously confirmed their presence in COCs and cumulus mRNA. It is therefore likely that expression in the former was reflective of transcripts in the cumulus cell component. In contrast, both BDNF and p75 could be detected in maturing and MII arrested oocytes sampled $26 \mathrm{~h}$ post in vitro maturation (IVM) in five independent trials.

\section{Immunohistochemistry for BDNF and associated receptors}

We next evaluated whether BDNF and its receptors could be localised in the bovine ovary and COCs by immunohistochemistry. BDNF specific staining was evident in both oocytes and granulosa cells of preantral and antral follicles, and in expanded cumulus and oocytes following IVM (Fig. 2). While BDNF expression in oocyte cytoplasm was only faint in ovarian tissue sections, it was more marked in isolated COCs (Fig. 2C). Cumulus cells also exhibited strong immunostaining. Some immunostaining of the theca cell layer surrounding antral follicles was also evident, as was prominent staining of vascular endothelial cells (Fig. 2B). No staining was detected in negative controls, following preabsorption of the primary antibody with BDNF peptide (Fig. 2D-F).

A similar pattern of distribution as for BDNF was also evident for p75. Thus p75 was expressed by granulosa cells of preantral and antral follicles (Fig. 2G and $2 \mathrm{H}$ ), with faint staining of theca cells surrounding antral follicles (Fig. 2H). Oocytes of isolated COCs were positive for p75-specific immunohistochemical staining (Fig. 2l). We were unable to obtain clear specific immunostaining for TrkB, although staining was detected in rat brain as a positive control (not shown).

\section{Effect of BDNF on maturation of cumulus-enclosed oocytes to MII}

To evaluate the effect of BDNF on bovine oocyte maturation, cumulus-enclosed oocytes were matured in the presence (positive control) or absence (negative control) of $10 \%$ FCS, or in serum-free media supplemented with 10 or $100 \mathrm{ng} / \mathrm{ml} \mathrm{BDNF}, 5 \mu \mathrm{g} / \mathrm{ml}$ anti-BDNF blocking antibody alone, or the latter with $10 \mathrm{ng} / \mathrm{ml}$ BDNF. All oocytes in each treatment group had undergone germinal vesicle breakdown (GVBD) by the time they were analysed. In total $77 \%$ of COCs in maturation medium containing FCS were scored as MII arrested after $26 \mathrm{~h}$ of culture. This was $2-3$-fold greater $(P<0.01)$ than that observed in all other treatment groups, between which there was no significant difference in outcome (Fig. 3). Thus, supplementation of serum-free maturation medium with BDNF was insufficient to substitute for the known benefit of serum to 

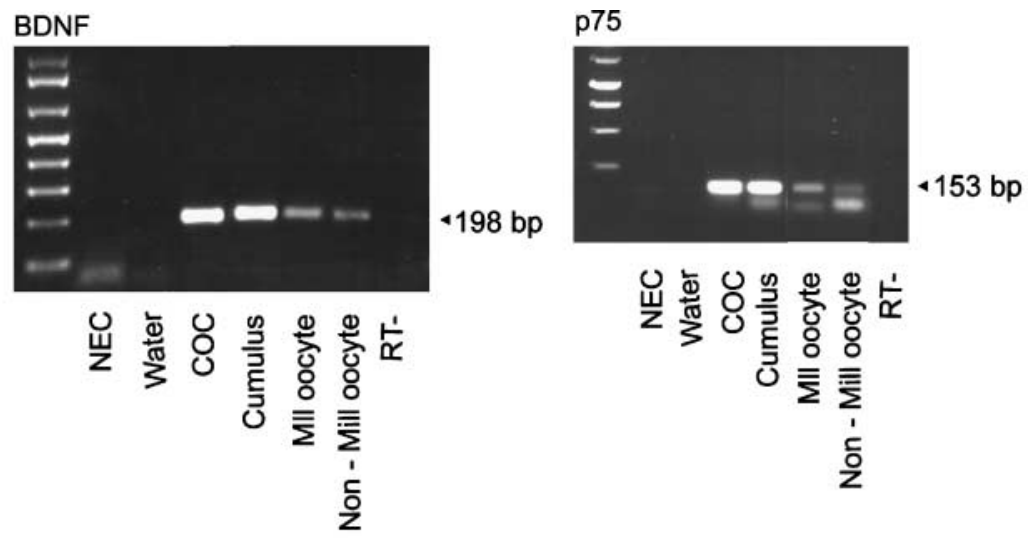

TrkB

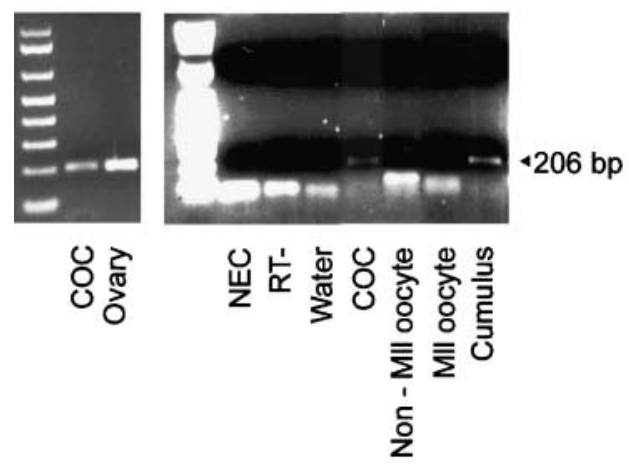

support nuclear maturation, when assessed at a single point in time when oocytes should have reached MII. Furthermore, a blocking antibody to BDNF did not have any additive detrimental effect on nuclear maturation above that observed for serum-free maturation in general.

\section{Effect of BDNF during maturation of cumulus-enclosed oocytes on parthenogenetic embryo development}

Parthenogenetic embryo development to cleavage and blastocyst stages were evaluated following activation of oocytes matured as COCs in the previously defined treatment groups. In these trials, no attempt was made to score maturation status of oocytes following IVM, thus most oocytes, except those damaged during removal of cumulus, subsequently underwent parthenogenetic activation, irrespective of maturation status. In a first series consisting of three replicate trials, COCs matured without serum and activated (total $n=83$ ) were compared with those matured with FCS $(n=103)$ or either $10(n=95)$ or $100 \mathrm{ng} / \mathrm{ml} \mathrm{BDNF}(n=91$; Fig. $4 \mathrm{~A}-\mathrm{C})$. Evaluating the proportion of activated oocytes undergoing first cleavage after $24 \mathrm{~h}$, there were no significant differences across treatment groups (serum-free, 63\%; FCS, 65\%; $10 \mathrm{ng} / \mathrm{ml}$ BDNF, 65\%; $100 \mathrm{ng} / \mathrm{ml} \mathrm{BDNF,} \mathrm{74 \% ;} \mathrm{Fig.} \mathrm{4A).} \mathrm{By} \mathrm{contrast,}$ the proportion of activated oocytes forming blastocysts following maturation with $10 \mathrm{ng} / \mathrm{ml}$ BDNF was over 1.5-fold higher $(P<0.01)$ than with FCS, which was equivalent to the higher concentration of BDNF. Blastocyst yields in all treatment groups were also significantly higher than oocytes matured without serum (serum-free, 10\%; FCS, $15 \% ; 10 \mathrm{ng} / \mathrm{ml}$ BDNF, 24\%; $100 \mathrm{ng} / \mathrm{ml}$ BDNF, 18\%; $P<0.01)$. Improved blastocyst development following maturation with the lower concentration of BDNF was also apparent if calculated relative to the number of cleaved embryos (serum-free, 15\%; FCS, 22\%; $10 \mathrm{ng} / \mathrm{ml}$ BDNF, 37\%; $100 \mathrm{ng} / \mathrm{ml} \mathrm{BDNF,} \mathrm{24 \% ;} P<0.01$ ).

In a second series of three replicate trials, the development of COCs matured without serum was compared against those matured with $10 \mathrm{ng} / \mathrm{ml}$ BDNF (the best treatment in the previous series), $10 \mathrm{ng} / \mathrm{ml} \mathrm{BDNF}+5 \mu \mathrm{g} / \mathrm{ml}$ blocking antibody, or $5 \mu \mathrm{g} / \mathrm{ml}$ blocking antibody alone. The proportion of activated oocytes undergoing first cleavage after $24 \mathrm{~h}$ was significantly lower following maturation with the blocking antibody alone $(30 \%, n=81) \mathrm{vs}$ all of the other treatment groups (i.e. serum-free, $64 \%$, $n=83 ; 10 \mathrm{ng} / \mathrm{ml} \mathrm{BDNF}, 60 \%, n=85 ; 10 \mathrm{ng} / \mathrm{ml} \mathrm{BDNF}+$ blocking antibody, 63\%, $n=76 ; P<0.01)$. Blastocyst yields in this experimental series were generally poorer than that observed in the first series, possibly due to seasonal variations in oocyte quality commonly encountered with abattoir derived ovaries. Despite this, treatment with $10 \mathrm{ng} / \mathrm{ml}$ BDNF yielded significantly more blastocysts per activated oocytes vs any of the other treatment groups (10 ng/ml BDNF, 9\%; serum-free, 2\%; BDNF + blocking antibody, 4\%; blocking antibody alone, 4\%; $P<0.01$ ). Evaluating blastocyst nuclear counts for each treatment 


\section{BDNF}
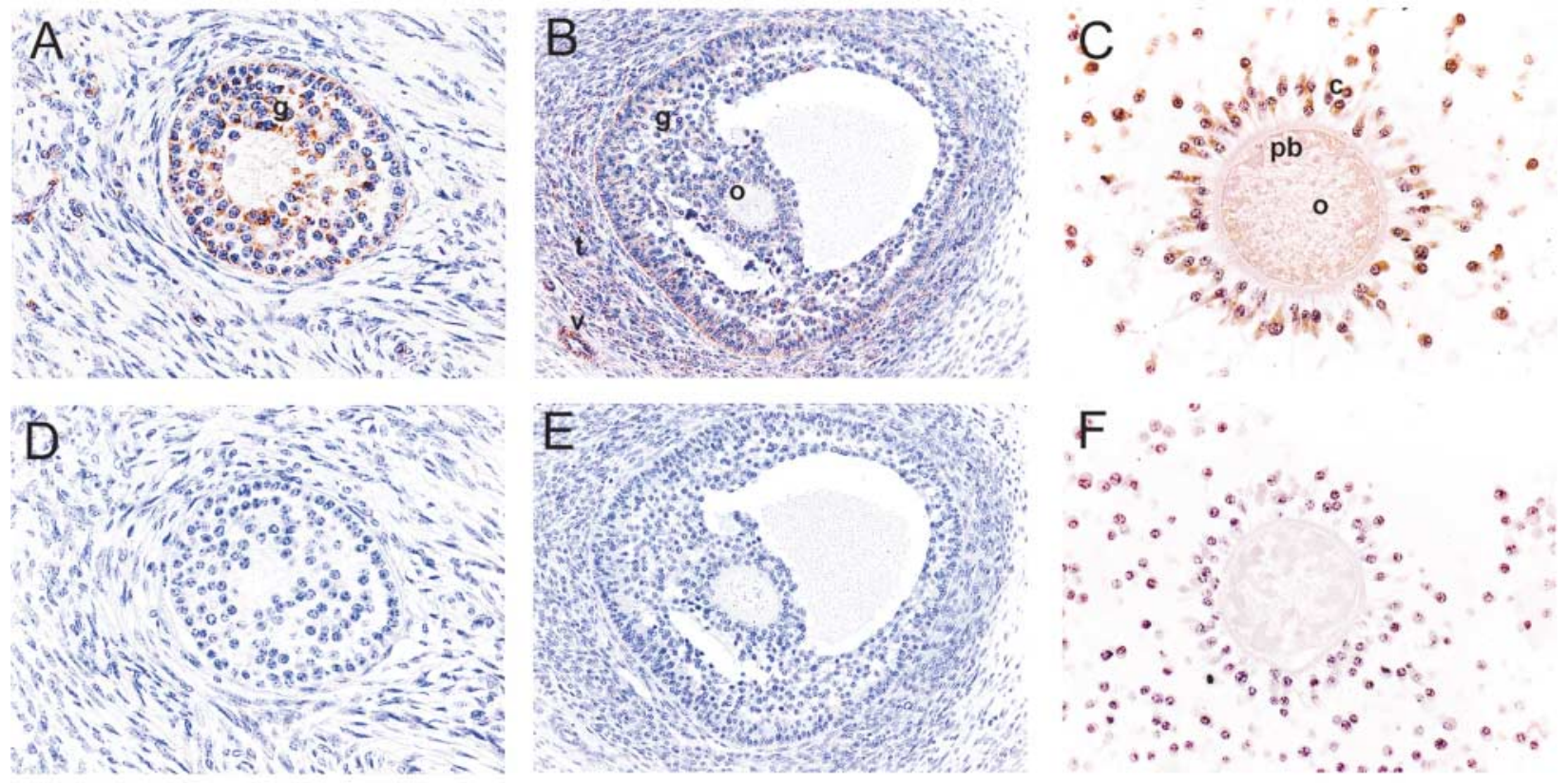

\section{p75}
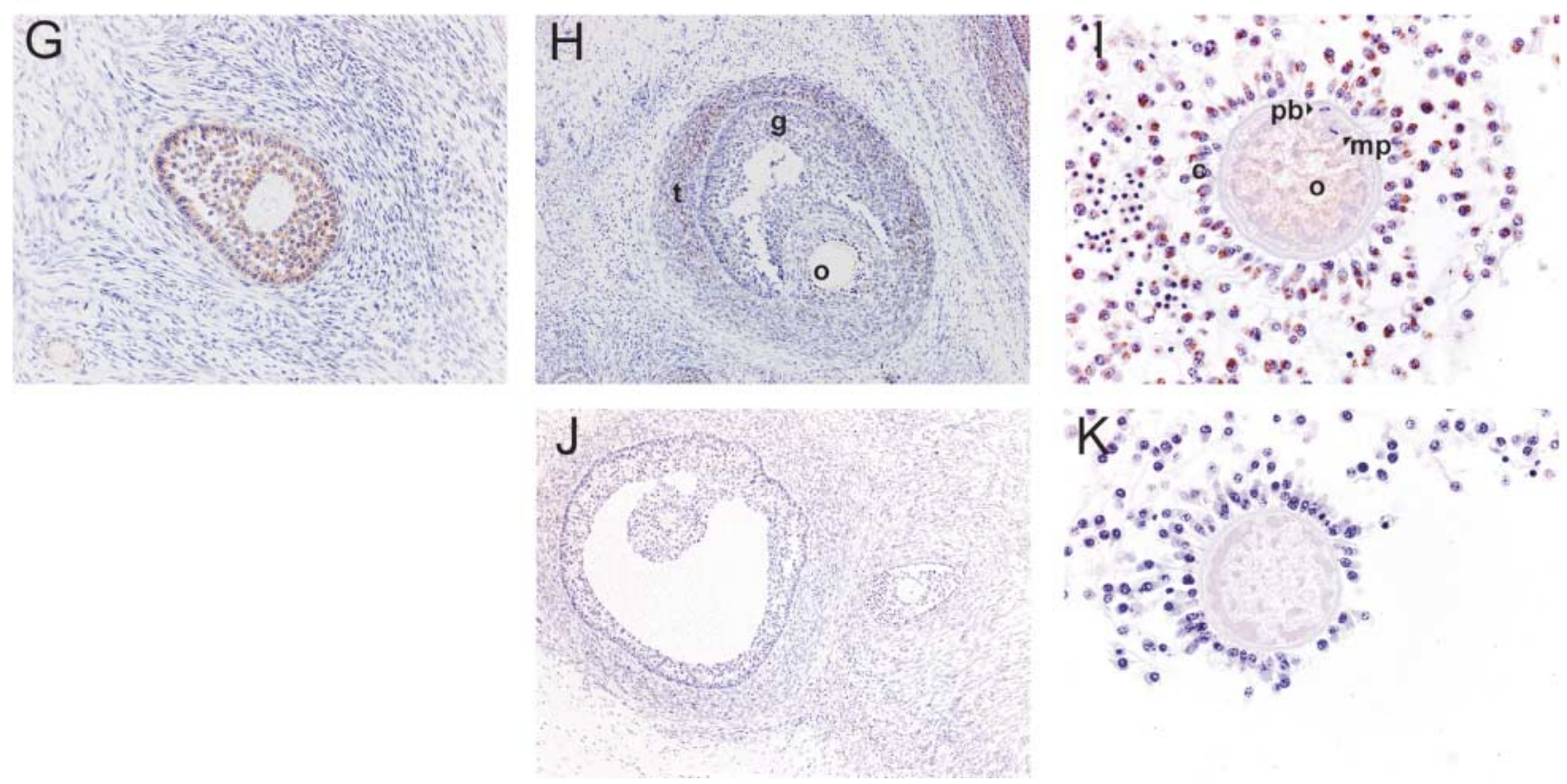

Figure 2 Immunohistochemical staining for BDNF and p75 in bovine ovarian follicles and cumulus oocyte complexes (COCs). BDNF specific immunostaining was evident in both oocytes (o) and granulosa (g) cells of preantral (A) and antral (B) follicles and in cumulus (C) and oocytes following in vitro maturation of isolated COCs (C). Some immunostaining of the theca (t) cell layer surrounding antral follicles was also evident, as was prominent staining of vascular ( $\mathrm{v}$ ) endothelial cells. In matched serial sections, this staining was blocked (D-F) if the primary antibody was first pre-incubated with the BDNF blocking peptide. Immunostaining for p75 (G-l) which was above that observed following omission of the primary antibody $(\mathrm{J}, \mathrm{H})$, was also detected in the granulosa and thecal cell layer of preantral $(\mathrm{G})$ and antral follicles $(\mathrm{H})$, and in oocytes and cumulus cells of in vitro matured COCs $(\mathrm{I}, \mathrm{J})$, Polar bodies $(\mathrm{pb})$ and a metaphase plate $(\mathrm{mp})$ are labelled. 


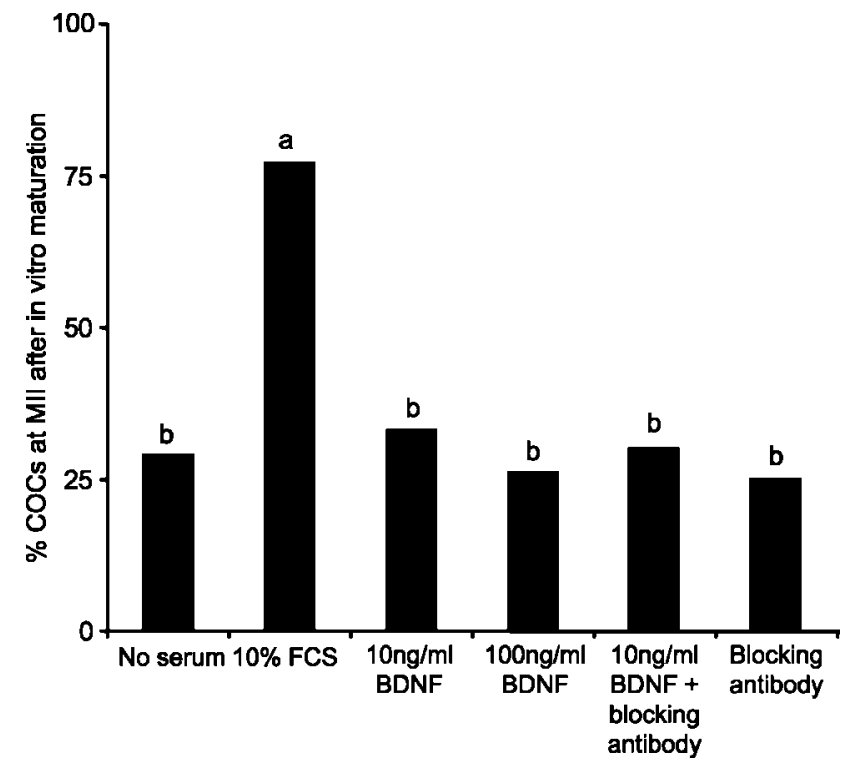

Figure 3 Effect of BDNF on maturation of cumulus-enclosed oocytes to MII. COCs were matured in the presence (positive control) or absence (negative control) of $10 \%$ FCS, or in serum-free media supplemented with 10 or $100 \mathrm{ng} / \mathrm{ml}$ BDNF, $5 \mu \mathrm{g} / \mathrm{ml}$ anti-BDNF blocking antibody alone, or the latter with $10 \mathrm{ng} / \mathrm{ml}$ BDNF. The experiment was repeated four times to arrive at the average proportion of oocytes at MII after $26 \mathrm{~h}$ of culture. Different letters denote significant differences $(P<0.01)$. Number of COCs per group: serum-free $n=49$; $10 \%$ FCS $n=43 ; 10 \mathrm{ng} / \mathrm{ml} \mathrm{BDNF}, n=49 ; 100 \mathrm{ng} / \mathrm{ml} \mathrm{BDNF}, n=47 ;$ $5 \mu \mathrm{g} / \mathrm{ml}$ anti-BDNF, $n=48 ; 10 \mathrm{ng} / \mathrm{ml}$ BDNF $+5 \mu \mathrm{g} / \mathrm{ml}$ anti-BDNF, $n=47$.

within and between experiment trials revealed no significant differences (i.e. for each treatment group, means \pm S.E.M., serum-free, $68 \pm 8, n=12 ;$ FCS, $68 \pm 5, n=15$; $10 \mathrm{ng} / \mathrm{ml} \quad$ BDNF, $65 \pm 6, \quad n=31 ; \quad 100 \mathrm{ng} / \mathrm{ml} \quad$ BDNF, $77 \pm 6, \quad n=16 ; \quad 10 \mathrm{ng} / \mathrm{ml}$ BDNF + blocking antibody, $54 \pm 6, n=3$; blocking antibody alone, $63 \pm 10, n=3$ ).

\section{Effect of BDNF on maturation of cumulus-free oocytes to $\mathrm{MII}$}

To evaluate the effect of BDNF on bovine oocyte maturation without cumulus, germinal vesicle oocytes were denuded at the time of collection and matured in medium with or without $10 \% \mathrm{FCS}$, or in serum-free media supplemented with $10 \mathrm{ng} / \mathrm{ml}$ BDNF, $10 \mathrm{ng} / \mathrm{ml}$ BDNF +5 $\mu \mathrm{g} / \mathrm{ml}$ anti-BDNF blocking antibody, or $5 \mu \mathrm{g} / \mathrm{ml}$ antiBDNF blocking antibody alone. These were compared against cumulus enclosed oocytes matured with $10 \%$ FCS (positive control). At the time of analysis all oocytes had undergone GVBD. Similar to the first maturation experiment evaluating BDNF on cumulus enclosed oocytes, $71 \%(n=73)$ of COCs matured with FCS were scored as MII arrested after $26 \mathrm{~h}$ of culture. This was significantly higher than cumulus-free oocytes matured with FCS (39\%, $n=69 ; \quad P<0.01$ ), which in turn was approximately double $(P<0.01)$ that observed in all of the other treatment groups (i.e. serum-free, $22 \%, n=69 ; 10 \mathrm{ng} / \mathrm{ml}$
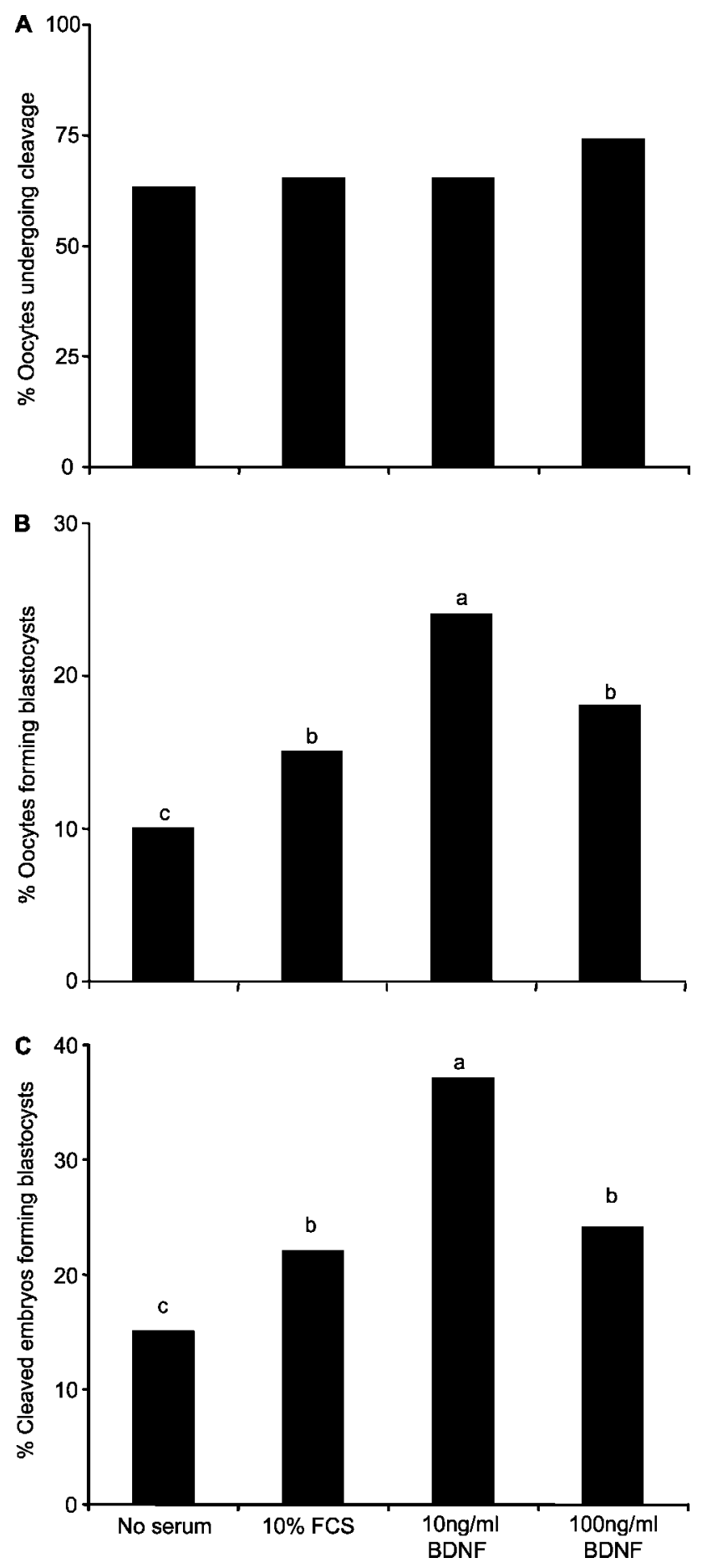

Figure 4 Development of parthenogenetic embryos following in vitro maturation of cumulus-enclosed oocytes with BDNF. COCs were matured in the presence (positive control) or absence (negative control) of $10 \%$ FCS, or in serum-free media supplemented with $10 \mathrm{ng} / \mathrm{ml}$ or $100 \mathrm{ng} / \mathrm{ml}$ BDNF, then activated. Data from three replicate trials were pooled to arrive at the average proportion of activated eggs undergoing cleavage (A) or forming blastocysts (B), or the proportion of cleaved embryos forming blastocysts (C). Different letters (a-b) denote significant differences $(P<0.01)$. Number of activated oocytes per group: +FCS, $n=103$; serum-free, $n=83 ; 10 \mathrm{ng} / \mathrm{ml}$ BDNF, $n=95 ; 100 \mathrm{ng} / \mathrm{ml} \mathrm{BDNF,} n=91$. 
BDNF, 25\%, $n=71$; BDNF + blocking antibody, 19\%, $n=36$; and blocking antibody alone, $18 \%, n=49$ ). Thus, although progression to MII is generally poorer in the absence of cumulus cells, exogenous BDNF cannot substitute for serum to support nuclear maturation in the presence or absence of cumulus cells. Furthermore, a blocking antibody to BDNF did not have any additive detrimental effect on nuclear maturation beyond that observed for serum-free maturation in general.

\section{Effect of BDNF during maturation of cumulus-free oocytes on parthenogenetic embryo development}

In a final series of experiments, parthenogenetic embryo development to cleavage and blastocyst stages was evaluated following activation of oocytes matured in the absence of cumulus cells as described above. As with the activation experiments involving cumulus-enclosed maturation, the maturation status of oocytes was not scored and all morphologically intact oocytes were activated. This design was repeated in 5 replicate trials, each of which also included a positive control of COCs matured with $10 \%$ FCS (Fig. $5 \mathrm{~A}-\mathrm{C}$ ). The proportion of activated oocytes that had cleaved by $24 \mathrm{~h}$ was significantly higher for COCs and stripped oocytes matured with FCS and stripped oocytes matured with BDNF, vs all of the other treatment groups (i.e. COCs + FCS, $61 \%, n=114 ;$ stripped + FCS, $53 \%, n=119$; stripped serum-free, $32 \%, \quad n=115 ; \quad 10 \mathrm{ng} / \mathrm{ml} \quad B D N F, \quad 43 \%$, $n=116 ; \quad 10 \mathrm{ng} / \mathrm{ml} \quad$ BDNF + blocking antibody, $29 \%$, $n=118$; blocking antibody alone, $28 \%, \quad n=120$; $P<0.05)$. Similarly, the proportion of activated oocytes forming blastocysts was significantly highest for COCs matured with FCS (33\%). Cumulus-free oocytes matured with serum $(13 \%)$ or $10 \mathrm{ng} / \mathrm{ml}$ BDNF $(7 \%)$ were in turn significantly different from BDNF with blocking antibody $(4 \%)$, and serum-free $(2 \%)$, with no blastocysts formed by treatment with blocking antibody alone $(P<0.01)$. A similar relationship between treatment groups was observed if blastocyst yields were expressed relative to numbers of cleaved embryos $(P<0.01)$, with the exception that there no longer was a significant difference between BDNF and BDNF with blocking antibody. Irrespective of differences in the proportion of embryos forming blastocysts there were no differences in blastocyst nuclear counts between cumulus-free treatment groups (means \pm S.E.M: stripped + FCS, $61 \pm 4, n=15$; stripped serum-free, $53 \pm 13, n=2 ; 10 \mathrm{ng} / \mathrm{ml}$ BDNF, $57 \pm 6, \quad n=8 ; \quad 10 \mathrm{ng} / \mathrm{ml} \quad$ BDNF + blocking antibody, $59 \pm 5, n=5$ ). However, blastocyst nuclear counts for COCs matured in medium containing serum were significantly higher than cumulus-free groups $(85 \pm 8$, $n=38 ; P<0.01$ )

These findings suggest that BDNF can substitute for serum but not cumulus cells during IVM in order to support oocyte competence to form parthenogenetic blastocysts. The capacity of IVM treatment with blocking
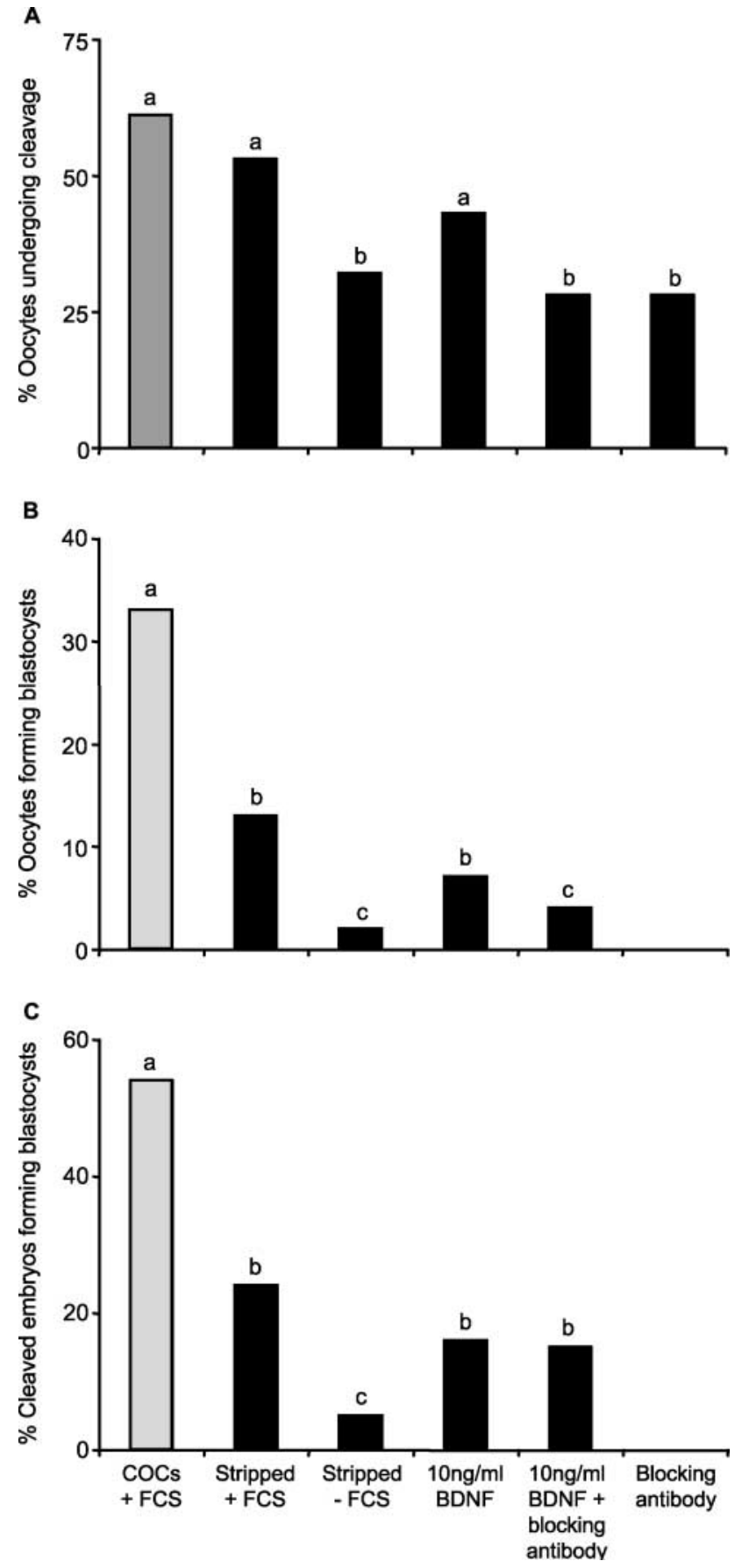

Figure 5 Development of parthenogenetic embryos following in vitro maturation of cumulus-free oocytes with BDNF or blocking antibody. Germinal vesicle oocytes were denuded at the time of collection and matured in medium with or without $10 \%$ FCS (serum), or in serumfree media supplemented with $10 \mathrm{ng} / \mathrm{ml}$ BDNF, $10 \mathrm{ng} / \mathrm{ml}$ BDNF + BDNF blocking antibody, or blocking antibody alone prior to activation. Data from five replicate trials were pooled to arrive at the average proportion of activated eggs undergoing cleavage (A) or forming blastocysts (B), or the proportion of cleaved embryos forming blastocysts (C). Significant differences denoted by different letters (a-c; $P<0.01)$. Number of activated oocytes per group: COCs + FCS, $n=114$; stripped oocytes + FCS, $n=119$; stripped oocytes FCS, $n=115 ; 10 \mathrm{ng} / \mathrm{ml} \mathrm{BDNF,} n=116 ; 10 \mathrm{ng} / \mathrm{ml}$ BDNF with blocking antibody, $n=118$; blocking antibody alone, $n=120$. 
antibody to completely block blastocyst formation suggests that BDNF may also exert an influence on oocytes directly.

\section{Discussion}

Using a bovine oocyte IVM and parthenogenesis model system we have investigated the role of BDNF in conferring oocyte developmental competence. Both oocytes and cumulus express mRNA transcripts and protein for BDNF and the p75 receptor that has affinity for all neurotrophins, but transcripts for the full length and truncated forms of the specific TrkB receptor are confined to cumulus. BDNF cannot substitute for serum in supporting meiotic progression to MII during IVM of cumulus-enclosed or -free oocytes. Despite this it can increase or approach the yield of parthenogenetic blastocysts relative to serum mediated maturation of cumulus-enclosed or -free oocytes, respectively, via signalling pathways which are sensitive to a BDNF specific blocking antibody. These results suggest that BDNF plays a role in conferring oocyte cytoplasmic competence to support early embryo development, independently of nuclear maturation, and that this may involve both autocrine and paracrine signalling within COCs.

Our study relied on parthenogenesis rather than fertilisation to assess oocyte competence for embryonic development. In mammals parthenogenesis can yield viable offspring provided that parent-specific imprints regulating gene expression are overcome to permit the formation of a functional placenta (Kono et al. 2004). Without such manipulations, parthenogenesis still provides a valuable measure of oocyte competence to initiate a developmental program since development to the blastocyst stage is independent of epigenetic imprinting (Latham et al. 1994). Accordingly, it is commonly used to assess oocyte competence to support early development following somatic or pronuclear transfer (Liu et al. 2001, De Sousa et al. 2002). The method of parthenogenetic activation used in our study has previously been characterised to yield equivalent rates of development to the blastocyst stage in a direct comparison with fertilised oocyte cohorts, although with a significant reduction in resulting cell number, similar to the present results (De La Fuente \& King 1998).

Important roles for Trk B receptors in oocyte survival in both the perinatal period of primordial follicle formation and during the early stages of follicle growth have been demonstrated using mouse knockout models (Spears et al. 2003, Paredes et al. 2004). Unfortunately however, these models have failed to illuminate the roles for these receptors or BDNF in the later stages of ovarian follicle development and for oocyte competence, due to the neonatal lethalities that they invoke (Klein et al. 1993, Ernfors et al. 1994). BDNF, NT-4 and NT-3 have all been detected in adult human follicular fluid (Seifer et al. 2002b, Seifer et al. 2003). In vitro studies on human cumulus cells have also found that BDNF secretion can be stimulated by treatment with cAMP and human chorionic gonadotropin
(hCG), but not recombinant FSH (Feng et al. 2003). Both BDNF and NT-4, but not NT-3 also promoted first polar body extrusion in cumulus-free mouse oocytes matured in vitro, compared with those matured in the absence of serum or hormones (Seifer et al. 2002a,b). Accordingly, by immunohistochemistry these studies have reported that most mouse oocytes are positive for TrkB, the BDNF and NT-4 receptor tyrosine kinase, with no immunoreactivity for TrkC, the respective receptor for NT-3. By RT-PCR the present data show p75 but not TrkB isoform mRNAs in bovine oocytes. Furthermore, we found no difference between BDNF and serum-free treatment groups in the proportion of oocytes reaching MII, both of which were inferior to supplementation with serum. This may reflect a species difference.

Our current study provides the first evidence that BDNF may benefit oocyte competence for embryonic development without necessarily benefiting maturation. Whereas approximately $80 \%$ of oocytes matured with FCS (positive control) reached MII, this was reduced to $30 \%$ in all FCSfree experimental treatments, including those with BDNF. In succeeding trials there was no difference between BDNF and FCS treatment groups in the proportion of parthenogenetic embryos which cleaved $(\sim 60 \%)$, with blastocyst yields improved or matched by BDNF treatment. Serum-free IVM has previously been shown to yield significantly fewer oocytes reaching MII, $50-60 \%$ vs $80-$ $90 \%$ with serum (Lonergan et al. 1994, Ali \& Sirard 2002). Our serum-free MII yields were generally lower. If in the absence of serum BDNF is inhibitory to meiotic maturation, this would not have been apparent in our experiments. However there was no evidence of an inhibitory effect of BDNF on subsequent parthenogenetic development.

Cumulatively, our results indicate a role for BDNF in oocyte maturation enabling both early embryo cleavage and blastocyst formation. For both cumulus-enclosed and -free maturation, the effect of the BDNF blocking antibody was first manifested by a significant reduction in cleavage. Compared with the serum treatment group, the improvement or matching of blastocyst yields with exogenously supplied BDNF was not paralleled by improved cleavage. Since BDNF did not increase the quantity of cells in blastocysts, it is likely that its effect was on oocyte and embryo survival as opposed to the promotion of growth. Further work is necessary to determine if BDNF has a physiological role during oocyte maturation.

BDNF signalling between cumulus and oocytes may be bi-directional with functionally different consequences given that both cell types express BDNF and differentially express p75 and TrkB isoforms, namely oocytes lack the latter. Trk and p75 receptors do not bind directly to each other, but can be complexed together (Bibel et al. 1999, Lee et al. 2001). This allows the signalling pathways triggered by both receptors to interact. The association of the two receptor types results in higher affinity ligand binding and a greater discrimination between neurotrophins. Thus, 
BDNF, NT3 and NT4 can each bind to the TrkB receptor, but in the presence of $\mathrm{p} 75$, only BDNF provides a functional response (Bibel et al. 1999). In neurons, Trk receptors and their substrates can activate three main signalling cascades: 1) differentiation, via a Ras/Raf/ MEK/MAP kinase pathway; 2) cell survival (anti-apoptosis) by association with insulin receptor substrates leading to inactivation of proapoptotic proteins; and 3) calcium release from internal stores via PLC- $\gamma$ mediated production of $\mathrm{IP}_{3}$ and production of protein kinase $\mathrm{C}$, which in neurons plays a role in neurotrophin mediated neurotrophin release (for review see Bibel \& Barde 2000). All of these pathways may be relevant to follicular and oocyte maturation, but most striking is the potential for neurotrophin mediated stimulation of the MAP kinase pathway. Gonadotropin induced cumulus expansion and resumption of meiosis in oocytes is dependent upon activation of MAP kinase in granulosa cells. This activation is downstream of gonadotropin-induced elevation of granulosa cell cAMP, and is dependent upon one or more paracrine factors from the oocyte (Su et al. 2003). BDNF secretion by cumulus is another consequence of either gonadotropin stimulation or artificial elevation of cAMP. Elevated cAMP in cumulus could lead to the same in oocytes via gap junctions, culminating in BDNF secretion by oocytes that could act in an autocrine or paracrine fashion to augment the effect of cumulus-derived BDNF. It is unknown whether BDNF derived from oocytes or cumulus would differ in their bioactivity. Neurotrophins in general are substrates for pro-protein convertases that can alter the molecular bioactivity of their targets by proteolytic cleavage during intracellular and extracellular processing. BDNF is an especially well characterised example of convertase-dependent modulation of bioactivity (reviewed in Seidah \& Chretien 1999). Thus, differences in BDNF bioactivity could be achieved by differential expression of pro-protein convertases in cumulus and oocytes.

The functional consequences of ligand interaction with the p75 receptor are also complex, and in neurons have been linked to cell survival, arrest, differentiation, and programmed cell death. Recently the concept of p75 as a 'quality control' receptor has been advanced based on evidence that it is capable of mediating programmed cell death in response to either ligand binding or withdrawal. In essence the downstream consequence of ligand interactions are proposed to be dependent on the relative proportions of p75 and Trk receptors and which neurotrophin is present (Rabizadeh \& Bredesen 2003). According to this model, binding of neurotrophins to p75 in the absence of Trk receptors, typically suppresses apoptosis. This could be the case for bovine oocytes provided they do not express TrkA or TrkC receptors. From mouse knockout models, mice homozygous for a targeted mutation in p75, rendering it functionally inactive, are viable and fertile, although they eventually develop deficits in their peripheral sensory nerves characterised by heat sensitivity and susceptibility to ulceration (Lee et al. 1994). This suggests that the most critical role for p75 may be to ameliorate the effect of stress, which in the case of oocyte maturation and developmental competence, might be most affected by adverse in vitro culture environments.

A number of other growth factors have been reported to improve oocyte competence to support embryo development, when applied during oocyte maturation in vitro. Epidermal growth factor (EGF) improves the yield of fertilised bovine blastocysts, but not cell number, relative to serum-free culture conditions lacking hormones (Lonergan et al. 1996). However, this effect is preceded by promotion of the proportion of cumulus-enclosed or -free oocytes progressing to MII, the latter supporting a direct effect on oocytes. EGF-receptor tyrosine kinase mediated activation of meiosis was first described in Xenopus oocytes, and later confirmed in the rat and mouse (Maller 1985, Ueno et al. 1988, Downs 1989). Studies in the latter also revealed a direct effect of EGF on cumulus, leading to the promotion of cumulus expansion. Like EGF, other groups have demonstrated that supplementation of bovine oocyte IVM culture with exogenous activin A, promotes meiotic maturation and subsequent yield of fertilised blastocysts (Stock et al. 1997, Silva \& Knight 1998), an effect which is reduced by the activin binding protein follistatin. These gene products are synthesised by granulosa cells and are prominent components of follicular fluid (Braw-Tal 1994). Activin A receptor mRNA can be detected in both granulosa cells and oocytes (Cameron et al. 1994). In the former, activin A appears to increase the number of FSH receptors in granulosa cells and as such may promote gonadotropin action during maturation (Nakamura et al. 1993). A direct effect of activin A on oocytes is supported by evidence of improved progression to MII of cumulus-free oocytes, although the mechanism by which this is achieved is unknown (Stock et al. 1997). Activin A also promotes human germ cell survival and proliferation prior to primordial follicle formation (Martins da Silva et al. 2004). Only midkine, a heparin-binding growth/differentiation factor, which is also a prominent feature of bovine follicular fluid, is similar to BDNF in promoting oocyte competence to reach the blastocyst stage without also improving meiotic progression to MII (Ikeda et al. 2000). Midkine is also produced by granulosa cells under the control of gonadotropins (Minegishi et al. 1996). Unlike BDNF however, midkine does not appear to act directly on oocytes. Its actions can also be blocked by heparin (Ikeda et al. 2000).

In conclusion, our study adds BDNF to the list of growth factors, normally present in follicular fluid, which can specifically promote oocyte developmental competence during IVM. BDNF differs from most other factors identified however in that its effect is to promote cytoplasmic maturation without advancing nuclear maturation. This effect is likely to be complex and mediated by direct effects on both the oocyte and cumulus cells. This knowledge will be of value to the creation of completely defined culture environments free of serum for oocyte maturation, 
which will improve both their overall safety and the efficacy of assisted reproductive technologies applied to both animals and humans.

\section{Acknowledgements}

This research was supported by funding from the Medical Research Council (SMdS and RAA) and from Geron Corporation (Menlo Park, California, USA) to PDS.

\section{References}

Ali A \& Sirard MA 2002 Effect of the absence or presence of various protein supplements on further development of bovine oocytes during in vitro maturation. Biology of Reproduction 66 901-905.

Anderson RA, Robinson LLL, Brooks J \& Spears N 2002 Neurotropins and their receptors are expressed in the human fetal ovary. Journal of Clinical Endocrinology and Metabolism 87 890-897.

Bibel M \& Barde YA 2000 Neurotrophins: key regulators of cell fate and cell shape in the vertebrate nervous system. Genes and Development 14 2919-2937.

Bibel M, Hoppe E \& Barde YA 1999 Biochemical and functional interactions between the neurotrophin receptors trk and p75NTR. The EMBO Journal 18 616-622.

Braw-Tal R 1994 Expression of mRNA for follistatin and inhibin/activin subunits during follicular growth and atresia. Journal of Molecular Endocrinology 13 253-264.

Cameron VA, Nishimura E, Mathews LS, Lewis KA, Sawchenko PE \& Vale WW 1994 Hybridization histochemical localization of activin receptor subtypes in rat brain, pituitary, ovary, and testis. Endocrinology 134 799-808.

Chian R-C, Buckett WM \& Tan SL 2004 In vitro maturation of human oocytes. RBM Online 8 148-166.

De La Fuente R \& King WA 1998 Developmental consequences of karyokinesis without cytokinesis during the first mitotic cell cycle of bovine parthenotes. Biology of Reproduction 58 952-962.

De Sousa PA, Dobrinsky JR, Zhu J, Archibald AL, Ainslie A, Bosma W, Bowering J, Bracken J, Ferrier PM, Fletcher J, Gasparrini B, Harkness L, Johnston P, Ritchie M, Ritchie WA, Travers A, Albertini D, Dinnyes A, King TJ \& Wilmut I 2002 Somatic cell nuclear transfer in the pig: control of pronuclear formation and integration with improved methods for activation and maintenance of pregnancy. Biology of Reproduction 66 642-650.

Dissen GA, Hirshfield AN, Malamed S \& Ojeda SR 1995 Expression of neurotrophins and their receptors in the mammalian ovary is developmentally regulated: changes at the time of folliculogenesis. Endocrinology 136 4681-4692.

Dissen GA, Romero C, Hirshfield AN \& Ojeda SR 2001 Nerve growth factor is required for early follicular development in the mammalian ovary. Endocrinology 142 2078-2086.

Downs SM 1989 Specificity of epidermal growth factor action on maturation of the murine oocyte and cumulus oophorus in vitro. Biology of Reproduction 41 371-379.

Eppig JJ 2001 Oocyte control of ovarian follicular development and function in mammals. Reproduction 122 829-838.

Ernfors P, Lee KF \& Jaenisch R 1994 Mice lacking brain-derived neurotrophic factor develop with sensory deficits. Nature $\mathbf{3 6 8}$ $147-150$.

Feng B, Chen S, Shelden RM \& Seifer DB 2003 Effect of gonadotropins on brain-derived neurotrophic factor secretion by human follicular cumulus cells. Fertility and Sterility 80 658-659.

Ibanez CF, Hallbook F, Godeau F \& Persson H 1992 Expression of neurotrophin-4 mRNA during oogenesis in Xenopus laevis. International Journal of Developmental Biology 36 239-245.

Ikeda S, Ichihara-Tanaka K, Azuma T, Muramatsu T \& Yamada M 2000 Effects of midkine during in vitro maturation of bovine oocytes on subsequent developmental competence. Biology of Reproduction 63 1067-1074.
Izadyar F, Dijkstra G, Van Tol HTA, Van den Eijnden-van Raaij AJM, Van den Hurk R, Colenbrander B \& Bevers MM 1998 Immunohistochemical localization and mRNA expression of activin, inhibin, follistatin, and activin receptor in bovine cumulus-oocyte complexes during in vitro maturation. Molecular Reproduction and Development 49 186-195.

Jensen T \& Johnson AL 2001 Expression and function of brain-derived neurotrophin factor and its receptor, TrkB, in ovarian follicles from the domestic hen (Gallus gallus domesticus). Journal of Experimantal Biology 204 2087-2095.

Keskintepe L \& Brackett BG 1996 In vitro developmental competence of in vitro-matured bovine oocytes fertilized and cultured in completely defined media. Biology of Reproduction 55 333-339.

Klein R, Smeyne RJ, Wurst W, Long LK, Auerbach BA, Joyner AL \& Barbacid M 1993 Targeted disruption of the trkB neurotrophin receptor gene results in nervous system lesions and neonatal death. Cell 75 113-122.

Kono T, Obata Y, Wu Q, Niwa K, Ono Y, Yamamoto Y, Park ES, Seo JS \& Ogawa H 2004 Birth of parthenogenetic mice that can develop to adulthood. Nature 428 860-864.

Krisher RL \& Bavister BD 1999 Enhanced glycolysis after maturation of bovine oocytes in vitro is associated with increased developmental competence. Molecular Reproduction and Development 53 19-26.

Latham KE, Doherty AS, Scott CD \& Schultz RM 1994 Igf2r and Igf2 gene expression in androgenetic, gynogenetic, and parthenogenetic preimplantation mouse embryos: absence of regulation by genomic imprinting. Genes and Development 8 290-299.

Lee FS, Kim AH, Khursigara G \& Chao MV 2001 The uniqueness of being a neurotrophin receptor. Current Opinion in Neurobiology $11281-286$.

Lee KF, Davies AM \& Jaenisch R 1994 p75-deficient embryonic dorsal root sensory and neonatal sympathetic neurons display a decreased sensitivity to NGF. Development 120 1027-1033.

Liu H \& Aoki F 2002 Transcriptional activity associated with meiotic competence in fully grown mouse GV oocytes. Zygote $\mathbf{1 0}$ $327-332$.

Liu H, Krey LC, Zhang J \& Grifo JA 2001 Ooplasmic influence on nuclear function during the metaphase II-interphase transition in mouse oocytes. Biology of Reproduction 65 1794-1799.

Liu J, Van Der Elst J \& Dhont M 2003 In vitro parthenogenetic development of mouse oocytes following reciprocal transfer of the chromosome spindle between in vivo-matured oocytes and in vitromatured oocytes. Biology of Reproduction 68 186-189.

Lonergan P, Carolan C \& Mermillod P 1994 Development of bovine embryos in vitro following oocyte maturation under defined conditions. Reproduction Nutrition Development 34 329-339.

Lonergan P, Carolan C, Van Langendonckt A, Donnay I, Khatir H \& Mermillod P 1996 Role of epidermal growth factor in bovine oocyte maturation and preimplantation embryo development in vitro. Biology of Reproduction 54 1420-1429.

Maller JL 1985 Regulation of amphibian oocyte maturation. Cell Differentiation 16 211-221.

Martins da Silva SJ, Bayne RA, Cambray N, Hartley PS, McNeilly AS \& Anderson RA 2004 Expression of activin subunits and receptors in the developing human ovary: activin A promotes germ cell survival and proliferation before primordial follicle formation. Developmental Biology $266334-345$.

Matsuda H, Coughlin MD, Beinenstock J \& Denburg J 1988 Nerve growth factor promotes human hemopoietic colony growth and differentiation. PNAS 85 6508-6512.

Messinger SM \& Albertini DF 1991 Centrosome and microtubule dynamics during meiotic progression in the mouse oocyte. Journal of Cell Science 100 (Pt 2) 289-298.

Minegishi T, Karino S, Tano M, Ibuki Y \& Miyamoto K 1996 Regulation of midkine messenger ribonucleic acid levels in cultured rat granulosa cells. Biochemical and Biophysical Research Communications 229 799-805. 
Nakamura M, Minegishi T, Hasegawa Y, Nakamura K, Igarashi S, Ito I, Shinozaki H, Miyamoto K, Eto Y \& Ibuki Y 1993 Effect of an activin $\mathrm{A}$ on follicle-stimulating hormone ( $\mathrm{FSH}$ ) receptor messenger ribonucleic acid levels and FSH receptor expressions in cultured rat granulosa cells. Endocrinology 133 538-544.

Paredes A, Romero C, Dissen GA, DeChiara TM, Reichardt L, Cornea A, Ojeda SR \& Xu B 2004 TrkB receptors are required for follicular growth and oocyte survival in the mammalian ovary. Developmental Biology 267 430-449.

Polak M, Scharfman R, Seilheimer B, Eisenbarth G, Dressler D, Verma IM \& Potter H 1993 Nerve growth factor induces neuronlike differentiation of an insulin secreting pancreatic beta cell line. PNAS 90 5781-5785.

Rabizadeh S \& Bredesen DE 2003 Ten years on: mediation of cell death by the common neurotrophin receptor p75(NTR). Cytokine and Growth Factor Reviews 14 225-239.

Rieger D, Luciano AM, Modina S, Pocar P, Lauria A \& Gandolfi F 1998 The effects of epidermal growth factor and insulin-like growth factor I on the metabolic activity, nuclear maturation and subsequent development of cattle oocytes in vitro. Journal of Reproduction and Fertility 112 123-130.

Schneider MB, Standop J, Ulrich A, Wittel U, Friess H, AndrenSandberg A \& Pour PM 2001 Expression of nerve growth factors in pancreatic neural tissue and pancreatic cancer. Journal of Histochemistry and Cytochemistry 49 1205-1210.

Seidah NG \& Chretien M 1999 Proprotein and prohormone convertases: a family of subtilases generating diverse bioactive polypeptides. Brain Research 848 45-62.

Seifer DB, Feng B, Shelden RM, Chen S \& Dreyfus CF 2002a Brainderived neurotrophic factor: a novel human ovarian follicular protein. Journal of Clinical Endocrinology and Metabolism 87 655-659.

Seifer DB, Feng B, Shelden RM, Chen S \& Dreyfus CF 2002b Neurotrophin- $4 / 5$ and neurotrophin-3 are present within the human ovarian follicle but appear to have different paracrine/autocrine functions. Journal of Clinical Endocrinology and Metabolism 87 4569-4571.

Seifer DB, Lambert-Messerlian G \& Schneyer AL 2003 Ovarian brain-derived neurotrophic factor is present in follicular fluid from normally cycling women. Fertility and Sterility 79 451-452.

Silva CC \& Knight PG 1998 Modulatory actions of activin-A and follistatin on the developmental competence of in vitro-matured bovine oocytes. Biology of Reproduction 58 558-565.
Spears N, Molinek MD, Robinson LL, Fulton N, Cameron H, Shimoda K, Telfer EE, Anderson RA \& Price DJ 2003 The role of neurotrophin receptors in female germ-cell survival in mouse and human. Development $1305481-5491$.

Stock AE, Woodruff TK \& Smith LC 1997 Effects of inhibin A and activin A during in vitro maturation of bovine oocytes in hormoneand serum-free medium. Biology of Reproduction 56 1559-1564.

Su YQ, Denegre JM, Wigglesworth K, Pendola FL, O'Brien MJ \& Eppig JJ 2003 Oocyte-dependent activation of mitogen-activated protein kinase (ERK1/2) in cumulus cells is required for the maturation of the mouse oocyte-cumulus cell complex. Developmental Biology 263 126-138.

Sutton ML, Gilchrist RB \& Thompson JG 2003 Effects of in vivo and in vitro environments on the metabolism of the cumulus-oocyte complex and its influence on oocyte developmental capacity. Human Reproduction Update 9 35-48.

Thompson JG, Gardner DK, Pugh PA, McMillan WH \& Tervit HR 1995 Lamb birth weight is affected by culture system utilised during in vitro pre-elongation development of ovine embryos. Biology of Reproduction 53 1385-1391.

Ueno S, Manganaro TF \& Donahoe PK 1988 Human recombinant mullerian inhibiting substance inhibition of rat oocyte meiosis is reversed by epidermal growth factor in vitro. Endocrinology 123 $1652-1659$.

Walker SK, Hill JL, Kleemann DO \& Nancarrow CD 1996 Development of ovine embryos in synthetic oviductal fluid containing amino acids at oviductal fluid concentrations. Biology of Reproduction 55 703-708.

Watson AJ, De Sousa P, Caveney A, Barcroft LC, Natale D, Urquhart J \& Westhusin ME 2000 Impact of bovine oocyte maturation media on oocyte transcript levels, blastocyst development, cell number, and apoptosis. Biology of Reproduction 62 355-364.

Young LE, Butterwith SC \& Wilmut I 1998 A novel method for quantifying mRNA levels in single embryos. Theriogenology 49192.

Received 26 August 2004

First decision 5 November 2004

Revised manuscript received 1 December 2004

Accepted 14 January 2005 